\title{
Instructional Time Loss in Developing Countries: Concepts, Measurement, and Implications
}

Helen Abadzi

Students in developing countries are often taught for only a fraction of the intended number of school hours. Time is often wasted due to informal school closures, teacher absenteeism, delays, early departures, and poor use of classroom time. Since the 1970s, attempts have been made in several countries to measure the use of instructional time in schools and its impact on student achievement. Studies have been of variable quality and have used different definitions and methods. However, they have consistently shown that significant amounts of time are lost and that the amount of time spent engaged in learning tasks is related to student performance. The large losses in many countries raise issues of governance, monitoring, and validity of economic analyses. It is important to take instructional time wastage into account when considering public sector expenditures on education, teacher salary rates, unit costs, and the rates of return from graduates. Refining time-loss measurement methods and disseminating policy implications may improve the efficiency of educational systems worldwide. JEL codes: I21, I22, I28, L23

To promote the Millennium Development Goals and universal primary school completion by 2015 , the international donor community has helped governments of developing countries pay for buildings, salaries, textbooks, and other inputs that would provide quality education. The implicit (though rarely stated) expectation was that this financing would purchase time and opportunities for students to interact with teachers in schools and engage in learning activities.

However, the numbers of instructional hours mandated by various governments are rarely implemented in many countries. Staff of donor agencies, during field visits, sometimes find schools closed, or that they start late or finish early, or that teaching lasts for a net of only $2-3$ hours a day. When teachers are present,

(C) The Author 2009. Published by Oxford University Press on behalf of the International Bank for Reconstruction and Development / THE WORLD BANK. All rights reserved. For permissions, please e-mail: journals.permissions@oxfordjournals.org doi;10.1093/wbro/lkp008ａdvance Access publication July 10, 2009 
Figure 1. Instructional Time-Loss Model

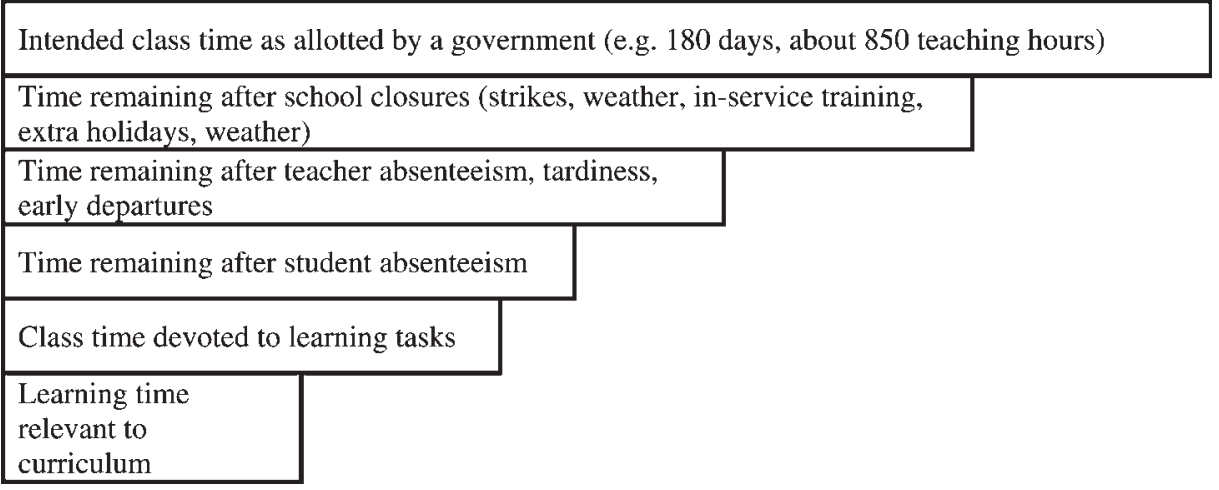

they may be engaged in other activities or let students play outside until visitors come. Precious class time may be spent in handing out textbooks, doing small chores, or copying from the blackboard. Teachers may interact only with the few students who perform and neglect the rest (see the time loss model in figure 1). In some of the classes observed, students may be unable to read and remain illiterate up to advanced primary grades (OED 2002, 2004, 2005; IEG 2008).

Surprisingly, little information has been available in most countries regarding the proportion of the intended instructional time that is actually used to engage students in learning and its relationship to student performance. Without this important mediator variable, policy advice has been hampered. Low performance may be attributed to reasons that are vague and not easily changeable, such as poverty, malnutrition, lack of incentives, or limited community involvement. Thus, there is a need to explore further the studies conducted on instructional time and understand why this topic has remained relatively obscure in the international economic literature.

The search for studies, results, and policy guidance has been challenging. Many studies have been conducted since the 1970s on some aspects of instructional time, and it would be desirable to compare and contrast their findings. However, study results are typically not comparable. There has been little agreement on what to measure and how to measure it. Many observation instruments and questionnaires have been used, some of which are more precise than others. Indicators for describing time loss range from numbers of completed book chapters to student self-reports and visual observations. Some indicators appear only once in the literature, and contexts are rarely the same. Sampling designs have been unclear or non-existent, and publications tend to give little detail on this issue. Often convenience samples were used, sometimes encompassing just a few 
schools or a single district. Studies linking student achievement to time loss have been correlational and often short term.

Despite methodological weaknesses, most studies point to substantial time loss, systemic inefficiency, and large-scale wastage of donor funds. The rationale linking student achievement with engagement in learning activities is fairly clear. Neuroscientific research shows why learners need prolonged and repeated exposure to stimuli along with feedback for error correction (Quartarola 1984; Rabenstein and others 2005; see Abadzi 2006 for a review of neuropsychological issues, including feedback and memory consolidation). Time wastage means that many countries have cohorts of poor students who simply do not get instruction sufficient for learning basic skills. This article attempts to summarize critically the existing research, point to measurement challenges in this area, and outline the reasons why valid and reliable measurement of instructional time is critical for governance and systemic efficiency. It also includes a study that attempted to develop internationally comparable instructional time measurements that can offer implementable policy advice to governments.

\section{Conceptualization of Instructional Time}

Considerations of time use started in the United States in the 1960s. In that period, some studies concluded that school was essentially a "black box" between inputs and outputs (Coleman and others 1966; Jencks 1972). The concept of instructional time use (sometimes called "opportunity to learn") gained more prominence in the 1970s, as mathematical learning models tried to show that optimal learning performance could be achieved by giving students sufficient time to learn (Carroll 1963; Atkinson 1972). In the 1970s and 1980s, many time usage studies were conducted, mainly in the United States. Research focused primarily on how time was used in the classroom, with particular concern placed on disciplinary disruptions. School-level time losses were not studied because in the United States and other high-income countries the school year is implemented as planned, and substitute teachers are used to cover for absent teachers. These earlier studies were published in peer-reviewed journals, but they tended to be rather weak. Observational instruments tended to rely on judgments, samples were small, and studies focused on specific states or school districts. Consequently, results have varied widely, showing that time spent on learning tasks ranged from 38 to 96 percent of available time (Smyth 1985; Anderson, Ryan, and Shapiro 1989; Fisher and others 1978). Nevertheless, school districts improved time management as a result of these studies, and administrators gradually lost interest in this measure. Few studies have taken place in the United States since the 1990s. 
Figure 2. Instructional Time Indicators in Basic Education of Some Middle Eastern Countries

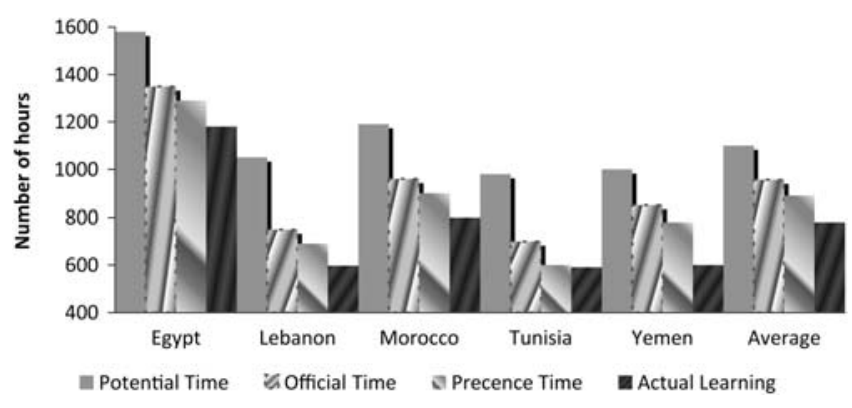

By contrast, studies in the international arena started in the 1990s. In lower income countries, sources of time loss tend to be multiple. Money for substitute teachers is rarely available, strikes and bureaucratic issues may delay school openings, matriculation periods may be long, infrastructure and climatic problems may lead to school closures. In crowded schools, time may be reduced so that all students can get some space. Concerns of governance and efficiency have grown as donor funding has increased, and demands for accountability have become stronger. For these reasons, studies were mainly commissioned by donor agencies and have usually not been published in peer-reviewed journals. (Notable exceptions are the teacher absenteeism studies conducted by the World Bank, such as Chaudhury and others 2004a, 2004b, 2004c.) Donor-financed studies measure different sets of variables and have varying degrees of methodological sophistication. Some were designed in detail, while others relied on self-reports and had poor controls or data reliability. Below are some examples of methods used and the results obtained from international studies:

- Analyses of internationally reported data. The UNESCO International Bureau of Education collects curricular data and occasionally reports on time use (Amadio 1997, 1998). Some peer-reviewed studies have analyzed this information. For example, Millot and Lane (2002; figure 2) found in several Middle Eastern countries considerable gaps amongst time as officially decreed and number of hours teachers actually taught.

- Ethnographic observations. This type of study may be a viable means of focusing on specific localities and extracting information for broader use. For example, a donor-commissioned study in eight low-income schools in Bangladesh found that they were open for 19 to 55 percent fewer days than had been scheduled in the school calendar. One month of contact time with students at the beginning and at the end of the school year was sacrificed to administrative and non-teaching activities. Rural schools allowed travel time for non-resident 
teachers and gave a 1.5-hour break to students attending Koranic school, but did not stay open later than scheduled. Inside the classroom, time was not used well, either. Teaching activities occupied on average 63 percent of the time in the classes observed; lecturing occupied about 83 percent of that time. There was also a high level of absenteeism amongst students: only 43-67 percent of them were in attendance on the days of surprise visits. Teachers estimated that only about 50 percent of the children were very regular in their attendance. The study found that the problems were more prominent in isolated areas. However, schools were more likely to comply with schedules if they received regular visits by the authorities (Tietjen, Rahman, and Spaulding 2004).

- Proportions of syllabi taught. An unpublished study undertaken in a Senegalese province by the inspectors of the Académie de Diourbel found a teacher absenteeism rate of about 30 percent, with strikes initiated by both students and teachers (Diouf 2005). In the final grade of secondary school, up to the final examinations, almost 5 weeks of class time were lost between October and March. With a teacher absenteeism rate of 32 percent, the deficit amounted to 112 hours or about 14 weeks. In the philosophy course, only 4 of the 23 chapters were covered, in physics only 7 of the 17 chapters, and in chemistry only 7 of the 11 chapters.

- Multiple visits to randomly sampled schools. Methodologically sophisticated studies have been financed by some donors, notably the United States Agency for International Development (USAID). These attempt to measure multiple levels of time loss (figure 1). Studies in Ghana and the Dominican Republic used random samples and repeated visits a few weeks apart. In the Dominican Republic, a team visited schools on three different occasions and noted the extent to which classes were operating. Overall, schools used 65 percent of the intended time in teaching, but afternoon shifts spent less time (58 percent) than morning shifts (73 percent) (EDUCA 2005).

\section{Sources of Instructional Time Loss}

To explain the concept and highlight issues more systematically, study results are presented below in accordance with the time-loss model (see figure 1). The degree to which studies were subject to peer review is indicated where possible. It is likely that reports commissioned by various agencies received less peer review than those published in peer-reviewed journals.

\section{Time Loss at the School Level}

Schools in some poorer countries systematically seem to open later or close earlier than the official timetables. For example, some schools in Bangladesh close the 
month before examinations so that students can prepare on their own. An unpublished study commissioned by the World Bank showed that in Burkina Faso over 16 percent of the official allocated time may be lost due to examinations and extended breaks during the day (Dia 2003). In the Dominican Republic, schools sampled by a USAID-financed study were imparting instruction for only 77 percent of the allocated time; the cancellation reasons included meetings with parents and district officials, teacher training, and strikes (EDUCA 2005). Strikes also accounted for closures in Honduras, where schools were reportedly open for only 114 days of the official 200 in 2001 (OED 2004). In Mali, an unpublished survey financed by the World Bank found that schools functioned for only 70 percent of the official time (Kim 1999), partly due to the delayed appointment of teachers and supervision weaknesses. In Nepal, donor-financed surveys showed schools operating on average for 3 hours a day, a fact that halved the available teaching time from over 1,000 hours to just 540 hours (Watkins 2000, p. 112). But overall, data on the incidence and rationale for school closures are sparse. More detailed research is needed to capture and quantify the various patterns of losses in order to inform policymakers.

\section{Time Loss Due to Teacher Absenteeism}

Teacher absenteeism has been the subject of well-designed and vetted studies. Several were conducted by World Bank staff (Chaudhury and others 2004b, 2004c; Patrinos and Kagia 2007), who reported absenteeism in primary schools, ranging from 11 percent in Peru to 27 percent in Uganda (table 1). Absenteeism has been studied in considerable detail in South Asia, where loss rates are high and improvements limited (Kremer and others 2005). Surveys of heath service providers, where available, suggest a broader effect of low-quality services to the poor.

Even when they are not absent, teachers may come to school late. This is an important and little-understood source of time loss, but data on this issue are limited (table 1). Teachers may also avoid teaching. For example, the PROBE study in India (De and Dreze 1999) found that in only 53 percent of the schools visited by the research staff were all teachers actually teaching in their classrooms; in 21 percent of the surveyed schools teachers were mainly "minding the class." In the remaining 26 percent they were talking with other teachers, sitting/standing outside the room, were in the head teacher's room, or were observed in other non-teaching activities.

Though correlation studies do not prove causality, published studies suggest that teacher absenteeism is related to lower student test scores in primary schools (Suryadarma and others 2004; Chaudhury and others 2004a). One study found that a 5 percent increase in the absenteeism rate of teachers who stayed with the 
Table 1. Rates of Teacher Absenteeism, Delay, and Failure to Teach (percent)

\begin{tabular}{lcccc}
\hline Country & $\begin{array}{c}\text { Teacher } \\
\text { absence }\end{array}$ & $\begin{array}{c}\text { Teacher } \\
\text { delay }\end{array}$ & $\begin{array}{c}\text { Teacher in school } \\
\text { but not in class }\end{array}$ & $\begin{array}{c}\text { Absenteeism in } \\
\text { primary health centers }\end{array}$ \\
\hline Bangladesh (Chaudhury and others & 16 & - & - & 35 \\
2004c) & 8 & - & - & - \\
Dominican Republic (EDUCA 2005) & 14 & - & - & - \\
Ecuador (Chaudhury and others 2004c) & 19 & 29 & & 40 \\
Ghana (EARC 2003) & 25 & - & - & - \\
India, national sample (Chaudhury and & & & & - \\
others 2004b) & 33 & - & 47 & - \\
India, rural north (De and Dreze 1999) & 20 & - & - & - \\
India, west Bengal (Sen 2002) & 36 & - & - & - \\
India, Udaipur non-formal education & & & - & - \\
$\quad$ centers (Duflo and Hanna 2005) & 19 & - & - & - \\
Indonesia (Chaudhury and others & & - & - & - \\
$\quad$ 2004c) & 21 & - & - & - \\
Indonesia (Suryadharma and others & & - & - & - \\
2004) & 28 & - & - & - \\
Kenya, regional study (Glewwe, Kremer, \\
and Moulin 1999)
\end{tabular}

- Not available.

Note: The Chaudhury and others 2004c study included health facility surveys, which are included for comparison.

same class for two years reduced student gains by 4-8 percent during the year; the size and precision of these estimates was the same for both math and English (Das and others 2005). In an Indonesian study, higher teacher absenteeism was related to lower fourth-grade student achievement on math (but not dictation) after controlling for household characteristics, teacher quality, and school conditions (study cited in Lewis and Lockheed 2006, p. 67). Some authors suggest that teacher absenteeism may encourage similar behavior among students in countries such as Mali and Somalia (Lockheed and Verspoor 1992; EARC 2003). Absenteeism may also perversely affect students' rates of promotion to the next 
grade. A vetted study in the Northwest Frontier Province of Pakistan (King, Orazem, and Paterno 1999) found that higher rates of teacher absenteeism increased student promotion rates for a given level of test scores but reduced student continuation rates. A likely explanation is that absent teachers make less accurate progress assessments and promote students who do not know enough and subsequently do not wish to continue their studies. Nevertheless, these well-designed studies do not focus on the amount and quality of time lost. Students of absent teachers may be unoccupied or attend other teachers' classes, and these two treatments are likely to have different learning outcomes. So, the effects of teacher absenteeism on student achievement need to be clarified through robust research designs.

The reasons for teacher absenteeism have been investigated to some extent (Rogers and others 2004). Some absenteeism is unavoidable, but absence rates are lower in countries with a higher per capita income. Higher absence rates are predicted by factors at the community level (remoteness, parents' education level), teacher level (teacher's professional or age-related seniority), and management level (physical infrastructure, multigrade teaching, inspection frequency). Increasing accountability to parents may result in lower absenteeism rates. For example, schools in Honduras, where communities are authorized by the government to pay teachers, had lower absenteeism rates than other rural schools. A completion report on a World Bank project reported that regular rural schools were open for 154 days a year, but community-managed schools operated for 180 of the 200 official days (World Bank 2008). This outcome is encouraging, but longitudinal research in more countries is needed to establish cause-effect relationships and conditions that inhibit or promote teacher absenteeism.

\section{Time Loss Due to Wastage of Classroom Time (Time on Task)}

Ideally, students should be engaged in learning during the entire time they are in class, particularly with activities that are more conducive to long-term memory consolidation of needed material and formation of useful linkages among pieces of information (Abadzi 2006). Schools in higher-income countries, that have trained teachers and a multitude of materials, may succeed in keeping most students suitably engaged most of the time. It is probably impossible to have 100 percent student compliance and time use, but some systems can become fairly efficient. For example, a published longitudinal study of eight elementary schools in Chicago found that 85 percent of the daily allocated time was dedicated to instruction (Smith 2000). (Other studies of the 1990s may not have been published in peer-reviewed journals.) Similarly, class-time use in Tunisia was measured at 86.7 percent (table 3).

In many countries, however, time in classrooms is not well used. The loss may be due to inadequate teacher knowledge and material resources. UNESCO reports 
suggest that poorly trained teachers may not know which activities result in efficient time use or why this concept matters (Attar 2001; Njie 2001). In countries such as the Gambia and Burkina Faso, textbooks are often scarce, and much class time may be lost writing out lessons and problems on the board (Dia 2003). The importance of time loss involved in copying was illustrated by a comparison of instructional time in three Latin American countries: few Brazilian schools used prepared activities, so students spent significantly more time copying math problems from the blackboard than did Chileans and Cubans. The test scores tended to reflect these differences (Carnoy, Gove, and Marshall 2004). However, it is not sufficient for students to have books: they must also know how to read and understand the texts in order to learn. In a Kenyan program where an NGO provided textbooks to all students, instructional time in classrooms improved, but a vetted study showed that test scores remained stagnant (Glewwe, Kremer, and Moulin 1999).

Students should not just be engaged in any learning activity, but should spend their time in activities that teach the prescribed curriculum. Students who do this are most likely to score well in achievement tests, so time spent on the curriculum may be a more useful predictor of learning outcomes than engagement in any learning activity (Vocknell 2006). Empirical information suggests considerable deviation in lower income countries. For example, in Ghana, a large portion of rural schoolteachers did not follow the prescribed weekly timetable (EARC 2003). Various possible reasons exist, including the likelihood that students may be too far behind in the official syllabus, or that teachers have a poor sense of the time needed to teach specific topics. However, little systematic information exists regarding the amount of time schools actually spent presenting new material and progressing with the specified curriculum. Curriculum measurement methods have been complex and dependent on local standards (for example, studies of students' notebooks; Ben Jaafar 2006). More research is needed to develop relatively simple means of measuring distance from expected curricular coverage.

Countries have increased their emphasis on quality and on instructional delivery in recent years, and an emerging issue is the neglect of lower scoring students. Teachers may engage the class in the required learning activities but interact with only the few students who can do the work. Many of the neglected students eventually drop out. The situation has been documented in World Bank evaluation reports (for example in Niger and Mozambique; OED 2005; IEG 2008), and there is published information on Jamaica (Lockheed and Harris 2005) and Albania (Sultana 2006). A published Greek study also found that the less-knowledgeable students spent more time "off task" (Matsagouras 1987). In Jamaica, the teachers of the higher primary grades concentrated on the few students who could pass the school leaving examinations. Albanian teachers directed questions 4.7 times more often to the better students than the failing ones, while the latter were uninvolved and asked no questions. This phenomenon, 
called "hidden dropout" in Albania, illustrates the complexities involved in measuring instructional time. It is not sufficient to document that instruction is going on; the percentage of students involved in it must be also measured.

Some studies have used quick assessments of whether or not a class is engaged in instruction (for example EDUCA 2005), but the reliability of this method and its relationship to learning outcomes have not been established. To estimate the percentage of students actually involved in instruction, targeted research may be justified using more sophisticated methods, such as instruments that register students' activities (for example experience sampling methods; Yair 2000).

\section{Relationships between Instructional Time, Poverty, and Achievement}

The bulk of educational research linking student achievement to engagement in learning outcomes is from the United States and dates from the 1970s to the early 1990s. The research has been published, but it has been mainly ex post facto, rather than experimental, and with poor controls. Analyses pre-date the use of hierarchical linear modeling and may have thus incorrectly estimated the variance accounted for by class or school effects. Nevertheless, the studies have consistently reported a positive relationship between instructional time and student achievement (Bloom 1971; Wiley and Harnishfeger 1974; Rosenshine 1979; Gettinger 1984, 1989; Fisher and Berliner 1985; Walberg 1988; Wang 1998; Lavy 2001). Such measurements are important given concerns about teacher attention to those who are better off (Lockheed and Harris 2005; Sultana 2006).

For example, an extensive review of U.S. studies concluded that, other things being equal, the amount learned is generally proportional to the time spent in learning (Fredrick and Walberg 1980). Two comprehensive reviews of research on learning effects demonstrated the positive influence of time on learning and the increasing precision in defining it: an earlier review of 35 studies showed positive effects had been found in 30 (86 percent) of the cases; while a later review of more than 100 studies showed positive influences in 88 percent of cases (Walberg and Fredrick 1991). Variables measuring curricular exposure are strong predictors of test scores, and correlations between content exposure and learning are typically higher than correlations between specific teacher behaviors and learning (Rosenshine 1979; Wang 1998). These positive relationships have been fairly consistent in studies employing different analytical perspectives, measurement strategies, and units of analysis (Huyvaert 1998).

Some published U.S. studies are quite pertinent to the World Bank's poverty alleviation mission. They suggest that the schools of the poor may make less time available to their students. Students from low-income families spend more time 
learning to read, with classroom interruptions and disruptions a salient problem (Stevens 1993). One longitudinal study in the United States found that high socioeconomic status students were engaged in writing, reading, and academic discussion for 5 percent more time per day than poorer students (Greenwood 1991). The study estimated that such students would need to attend school for one and a half months during the summer break in order to attain an equivalent amount of engaged learning time. Wastage adds up over the years and creates risks for poorer students. One educator named this problem the "pedagogy of poverty" (Stevens 1993).

Studies linking time, achievement, and poverty outside the United States have been relatively few, but trends have been similar. In a published review of 14 studies concerned with instructional time in developing countries, 12 studies showed a positive relationship between instructional time and achievement (Fuller 1987). More instructional time spent on general science was associated with higher academic achievement in Iran, India, and Thailand (Heyneman and Loxley 1983). In rural India student achievement was higher in schools with more instructional time; schools teaching the highest number of hours reported 66 more hours per year than schools with lower achievement (World Bank 1997). Increased student reading time had a positive effect on student achievement in Chile and India. School-based instructional time was found to be especially significant for children who got little school academic engagement after school hours (see Suryadi, Green, and Windman 1981 cited in Lockheed and Verspoor 1992). Instructional time was found to be one of three major areas (in addition to teacher quality and textbook availability) in which consistent achievement effects were obtained (Fuller and Clarke 1994). But studies have not captured all of the important dimensions of time loss and gain in lower income countries, so the magnitude and significance of the relationship between instructional time and educational achievement may seem uncertain (Anderson 1976; Karweit 1976, 1983). For example, in Pakistan it was found that teaching time by itself was a poor predictor of student achievement and that the effective use of time was a more accurate predictor (Reimers 1993).

\section{"Full-time" Schools}

The association between instructional time and achievement led some educators to favor additional hours and a longer school year for poor students. Some countries (notably Uruguay) have "full-time" schools that keep students for about 8 hours and offer many enrichment activities. A World Bank study showed that low-income students in Uruguayan full-time schools were 10 percent more likely to get passing scores in grade three over those attending regular schools (CerdanInfantes and Vermeersch 2007). (Full-time schools in Uruguay cost 60 percent 
more than regular schools and offer students extracurricular activities rather than extra instruction [OED 2005]). However, the effect is modest and suggests that merely increasing the time students are in school may have limited effects without an increase in the time students are actually engaged in learning (Karweit 1983).

\section{Tutoring}

To make up for instructional time lost to strikes, absenteeism, and lack of feedback parents have resorted to private tutoring. This is a major phenomenon worldwide that has grown dramatically in recent times and has affected the priorities of those who tutor. Families with the necessary resources are able to secure not only greater quantities but also better quality of private tutoring. According to a UNESCO publication, tutored children are able to perform better in school, whereas children of low-income families become disadvantaged (Bray 2006). This is one more way that the better-off get more instructional time than the poorer students. However, studies on tutoring have been hard to conduct, given the social reticence and the private nature of the instruction, so little hard information is available.

\section{The Effects of Split-shift Schooling}

In poorer countries, instructional time may also be lost due to the inefficiencies involved in large classes that in some cases exceed 100 students. To deal with large classes, countries like Senegal, Guinea, Bangladesh, Ghana, or Niger split a class into two and divide the time available between these two. Thus, a school day of five periods may be reduced to three for each class. This schedule is known as a split shift (or erroneously called double shift) and may result in a 19-30 percent loss of time (table 2). Some donor-financed studies have reported that this policy did not significantly impact on student performance (Bray 2000; World Bank and IADB 2000, p. 46), but this finding may be due to an already low quality of education (Linden 2001). For example, in Guinea students from split-

Table 2. Instructional Hours in African Countries Using "Split-shift" Schooling, per Year

\begin{tabular}{lcccccr}
\hline Type & Burkina Faso & Cote d'Ivoire & Guinea & Mali & Senegal & Average \\
\hline Standard classes & 858 & 754 & 747 & 888 & 675 & 784.4 \\
Split-shift classes & 603 & 580 & 585 & 645 & 547 & 592.0 \\
Difference (\%) & 29.7 & 23.0 & 21.6 & 23.7 & 18.9 & 24.5 \\
\hline
\end{tabular}

Note: Amounts averaged for all grades.

Source: Kim 1999. 
shift classes scored 3.6 percentage points lower in French and 5.6 points lower in math (Barrier and others 1998). An additional consequence may be higher teacher absenteeism, since this scheme is more demanding and repeating the same information to multiple classes may be tiring (Linden 2001; Suryadarma and others 2004). A World Bank-financed study in Guinea and Burkina Faso suggests that the split-shift arrangement particularly reduces time even further in the afternoon shift, and ought to have a negative impact on achievement (Dia 2003). The original plans in some countries called for the "off-shift" students to be occupied with schoolwork outside the class. However, it has often been impossible to organize teaching during off-shift hours, and children typically just go home. It seems that reductions in instructional time broadly affect vulnerable groups. In Egypt, girls attending multiple-shift schools with fewer instructional hours were five to six times more likely to drop out before completing lower secondary education than girls attending a single-shift school (Lloyd and others 2003).

\section{A Pilot of Internationally Comparable Time-loss Measurements}

Measuring time on task entails considerable complexity. Classroom-related variables are many, prioritization is difficult, and events constantly change. Many observation instruments have been developed. Some attempt to record behaviors precisely, while others demand inferences and judgments that are to some extent subjective. There are trade-offs to these approaches. The "low inference" instruments offer well-reasoned calculations of time loss and clear categories of behaviors to be observed, but the training of observers takes longer. For example, the Stallings Classroom Snapshot offers reliable quantitative data that include the percentage of students who appear to be "off task" through visual estimations. The instrument has been administered in six countries, and usable data have been obtained (see below). The information obtained is useful for the training of supervisors, and feedback to teachers on their use of time has been found effective for modifying their behavior (Stallings and Kaskowitz 1974; Stallings 1975, 1980, 1985a, 1985b; Stallings, Needles, and Stayrook 1979). However, the instrument requires about 5 days of training, observations to be made during an entire class hour, and complex estimations for producing several composite variables before data analysis.

A grant partnership program between the World Bank and the government of the Netherlands offered the opportunity to develop a holistic measure of instructional time loss and study its feasibility. The study assessed instructional time loss in four countries: Ghana, Morocco, Tunisia, and the Brazilian state of Pernambuco. Previously, qualitative evaluations referring to instructional time 
use had been conducted in two countries (Tunisia in 1998 and Morocco in 2001), while Ghana had been the focus of a 2004 World Bank impact evaluation. To pilot the use of instructional time data as a baseline for later project evaluation, the Brazilian state of Pernambuco was also included in the study.

\section{A Low-cost Time Estimation Methodology}

The aim was to develop an inexpensive measurement method that measured: (a) the number of days when schools were closed; (b) the time lost due to teacher absenteeism, tardiness, or early departures; (c) time use in classrooms; and (d) student absenteeism (which, however, overlaps with the other measures). A method was needed that would give stable estimates inexpensively, be administered within a few weeks, and capture time loss from multiple sources. Rather than making multiple school visits (as in absenteeism studies), estimates were obtained by triangulation.

Teams of three enumerators made a single unannounced visit to about 200 randomly sampled schools. In about 3 hours per school, the enumerators obtained information from the following stakeholders and sources: (a) direct observations of the operation of the school; (b) estimations by principals, teachers, students, and some parents regarding unplanned school closures, absenteeism, delays, and early departures; and (c) classroom observations of time use. Stakeholders were asked to estimate various sources of time loss for the current school year up to the date of the survey and on some variables for the previous school year. Questions to staff addressed the number of days of unplanned school closures; the number of days when teachers had been absent for any reason; teacher delays and early departures; the means to keep students occupied during teacher absences; and suggestions about improving time use. Opinions of cognitive psychologists were obtained regarding the time span during which recollection was likely to be accurate - the researchers experimented with time frames of 1 week, 1 month, and events since the beginning of the school year (see Abadzi 2007 for methodological details). Classroom-level observations were obtained through a specially adapted version of the Classroom Snapshot (Stallings 2006; Knight 2006). Training for the use of this instrument was conducted over 5 days and included attaining high standards of interrater reliability.

Following data processing, spreadsheets were produced to compare the frequencies of similar survey answers among the principals, teachers, students, and parents of each country (and ultimately across countries). Observed time loss was projected in the entire school year, taking holidays into account. Assumptions were made that time wastage was equally distributed throughout the year, that variations would be randomly distributed, and that surveys were equally likely to be filled at any working day of the week. Overall, information from the different 
informants at the school level was consistent. Time-loss estimates from multiple sources were averaged. A readministration of the surveys of 40 schools in Pernambuco, one and a half years after the first observation, gave some assurance of stability: the amount of time students were engaged in learning was calculated at 61.6 percent compared with 63 percent in the original sample.

In Tunisia, the country with the most efficient use of time, students were engaged in learning about 78 percent of the available time. In Ghana, however, students were engaged for only 39 percent of the time, and in Pernambuco 63 percent of the time. Morocco had indicators somewhat lower than those of Tunisia (using 71 percent of time for learning), but school closures may have been underreported. Translated into the number of days effectively available for learning, losses were palpable. For example, only 76.3 days were devoted to learning tasks of the 197 officially available to Ghanaian students, whereas 148.1 of the 190 days officially available were devoted to learning tasks for Tunisian students. In effect, Tunisian students get twice as much of the intended classroom time as Ghanaian students. The time-loss estimates presented in table 3 demonstrate the measurements that can be obtained through this method. These include the percentage of students appearing "off task" and an efficiency measure given students' off-task rate.

The study provided important lessons for creating a reliable and tightly structured package of surveys that scholars and governments can use relatively quickly and inexpensively. For example, school closures were underestimated because insufficient detail was obtained about various closure events. Parents turned out to have relatively little knowledge of school events (aside from their children's absenteeism and homework patterns) and could be dropped as a source of information in subsequent studies. Subsequently instruments were revised extensively and used in assessments of three other countries.

These measures, particularly when refined further, ought to be very useful for monitoring and evaluation purposes. Some consideration of designs would be necessary. If interventions in a country resulted in better educational management, the amount of time used for instruction should increase over a baseline and approximate to 100 percent, the amount that governments expect schools will devote to teaching. However, instructional time use is rarely mentioned explicitly during improvements are planned; baselines are either unavailable or pertain to a single variable (for example absenteeism). Without a baseline it is hard to determine the amount of increase, but a criterion-referenced approach could be taken. Curriculum developers in a country can be asked to estimate how many class hours students would need to master objectives of specific subjects in various grades and also to estimate the number of objectives likely to be missed if the available time were reduced in steps. In some subjects, the loss would be limited to that subject (for example social studies), but in others, like math, losses in 
grade one would impact on learning in higher grades and result in cumulative losses. It is possible to estimate and model these losses for evaluation purposes.

\section{Economic Implications of Instructional Time Use}

Why should economically oriented organizations spend resources to measure a concept that seems to be mainly educational? The research suggests that instructional time loss has significant economic implications. Government revenues pay for teachers' salaries, buildings, teacher training, and materials, and it is expected that 100 percent of this investment will be used for student learning. In fact, an hour of class in a particular school can be seen as a budgetary fraction corresponding to the amount of time schools officially operate (about 180 days, 4-5 hours per day at the primary level). It is possible to estimate the cost of time wastage down to the minute. Probably no schools use 100 percent of their time productively, but losses of the magnitude shown in the various studies suggest that schooling costs more than it ought to or achieves less for what it costs. So, data on instructional time loss have economic and monitoring implications. These include the following.

\section{Internal Efficiency Indicators}

The studies presented above suggest that, other things being equal, repetition and dropout rates are likely to be higher in a country which uses about 40 percent of instructional time for learning than in another which uses about 80 percent (for example Ghana versus Tunisia; table 3). For example, differential instructional time use may account to some extent for the large internal efficiency differences found between the Dominican Republic and Tunisia (per capita GDP US \$3,316 and US $\$ 2,860$ in 2005, respectively). Instructional time use was found to be 65 percent in the Dominican Republic and 78 percent in Tunisia (World Band 2008). The former had a dropout rate of 38.9 percent in 2005 whereas the latter had one of 5.6 percent. Also, survival to grade five was 97 percent for Tunisia but only 68 percent for the Dominican Republic. The changes in the indicators of these and other countries over time do not have clear reasons. Dropout could be due to external factors (for example the number of job opportunities or the effects of AIDS) or to limited instruction, but without time-loss measurements it is impossible to know.

\section{Teacher Salaries}

Systematic and extensive teacher absenteeism creates distortions. If wages are calculated based on the number of hours worked, teaching in some countries may 
Table 3. Instructional Time Use in the Four Countries of the Study

\begin{tabular}{lcrrr}
\hline & Pernambuco & & & \\
& (Brazil) & Ghana & Morocco & Tunisia \\
\hline Days of school year & \multicolumn{1}{c}{200} & 197 & 204 & 190 \\
Days schools closed & 4.79 & 3.17 & 1.38 & 5.15 \\
Number of days schools open & 195.21 & 193.83 & 202.62 & 184.85 \\
Teacher absence (days) & 12.76 & 43.01 & 13.36 & 11.55 \\
Teacher delays (days) & 5.50 & 39.75 & 6.94 & 1.27 \\
Early class dismissals (days) & 2.31 & 2.43 & 6.68 & 1.22 \\
No. of days schools operated for teaching & 174.65 & 108.6 & 175.6 & 170.8 \\
Percent of year available for teaching & 87.3 & 55.1 & 86.1 & 89.9 \\
Engagement rate in interactive or passive classroom & 72.1 & 70.2 & 82.6 & 86.7 \\
$\quad$ tasks (\%) & & & & \\
School days devoted to learning & 125.9 & 76.3 & 145.1 & 148.1 \\
Percent of school year engaged in learning tasks & 63.0 & 38.7 & 71.1 & 77.9 \\
\hline Student off-task rate (\%) & & & & \\
Instructional efficiency given off-task rate (\%) & 19.3 & 21.1 & 9.2 & 9.9 \\
Student absence (days) & 50.8 & 30.5 & 64.6 & 70.2 \\
Student delays (occasions) & 7.82 & 9.04 & 4.30 & 3.35 \\
& 5.64 & 10.61 & 5.19 & 2.63 \\
\hline
\end{tabular}

really be a part-time job, with higher hourly earnings than those formally calculated. Sometimes salaries are very low and efforts are made to raise them to acceptable levels, such as the frequently used benchmark of three times the per capita GDP. But before increasing salaries across the board, it is useful to ascertain how much teachers are paid for the work they actually do. (Dialog with teacher unions may focus on increasing instructional time.) An example to consider would be teacher salaries in Indonesia. The average estimated amount for civil service teachers is about US $\$ 2,400$ per year, which is about 1.7 times the per capita GDP of Indonesia. Absenteeism is estimated at 19 percent (Chaudhury and others $2004 \mathrm{c}$ ). At US $\$ 2,400$ and 23.5 hours of work per week, the hourly wage would be roughly US $\$ 2.8$, but, considering the number of hours actually worked, the wage would rise to about US $\$ 3.4$, and about US $\$ 456$ could be considered a "bonus." If teachers work at the same salary rate during the time they are absent, they could earn this extra amount and raise their very low salary to a more tolerable 2.1 times the per capita GDP. Some vetted studies have investigated teachers' activities during their absence, while others have estimated losses from absenteeism (Akhmadi and Suryadarma 2004; Patrinos and Kagia 2007). In countries of very low teacher pay, it would be possible to estimate the amounts of salary increase that would reduce absenteeism to acceptable levels (for example less than 10 percent). 


\section{Unit Costs and Rates of Return}

Rates of return to spending are made on actual spending, which is inclusive of instructional time effects. When time is wasted, however, governments assume that students get services that are not in fact provided. Perhaps unit costs per successful graduate should be used rather than unit costs per student, because they would more accurately reflect the real cost of providing services to students. Graduates' rates of return are calculated with the implicit expectation that students will be taught and will actually learn basic skills. Projections such as the amount of marginal earnings of an additional year of schooling may be unrealistic if students are served for only half the year or if they are illiterate and cannot benefit from the instruction. For example, Ghanaian students often need six years to become literate, but with an average time use of 39 percent this may not be surprising. In six years, they spend about as much time in classroom learning as students of higher-income countries spend in two years.

\section{Effects on Education Expenditures}

Some countries may devote a smaller percentage of their GDP to education but use time better, so they may use funds more efficiently than countries which spend more and waste more. Expenditures, measured as a share of GDP or of total public expenditures, do not show these differences. However, expenditures as a share of GDP are used to estimate financing needs for specific countries, and if the figures are considered low, efforts are made to increase them. Nevertheless, poor instructional time use will reduce the magnitude of expected effects. If a country doubles its education budget but still continues to use only half of the available instructional time, the extra financing will have a smaller impact than assumed. For example, Mozambique increased the per capita GDP spent in education from 4.3 percent in 2004 to 5 percent in 2005 . However, the poor time use observed in schools in 2007 (IEG 2008) raises doubts regarding the effects of this 0.6 percent increase on students' learning outcomes. Policy dialog aimed at increasing instructional time would be advisable before deciding to increase education expenditures.

\section{Continuing Social Inequity}

Primary education is generally considered to be more pro-poor than other levels of education, so it has more schools serving the poor than other levels of education. Since time may be used less well in the schools of the poor, assumptions about the pro-poor poverty alleviation effect of education may be unrealistic, and the equity effect may be lower than expected. This would affect benefit-incidence 
analyses and Lorenz curves. Additional public investment at that level may fail to mitigate poverty, unless it improves instructional delivery.

\section{Conclusions and Implications}

Despite methodological weaknesses, studies have consistently suggested that in many lower income countries or socioeconomic groups the time and opportunity to learn are limited, and this limitation is linked to student achievement. Thus, time is a mediator variable that has escaped scrutiny and measurement thus far. Without it, low performance may be attributed to reasons that are not easily actionable: poverty, malnutrition, lack of incentives, or poor community involvement.

The research suggests that it is not enough to provide the ingredients of instruction and assume that they will be used in class. Students must get sufficient time to master the instructional objectives intended in specific subjects. Inputs like teaching aids must be employed within the time frame available to students, or they may not promote student learning. The time devoted to learning the material prescribed by the curriculum may be the crux of educational "quality." The quantity-quality trade-off that is often mentioned in relationship to rapid expansion of education in developing countries may be mitigated if measures are taken to give students the instructional time that governments pay for, even as class sizes increase.

A focus on the instructional time concept opens many doors for improvement. There could be alternative ways of increasing education inputs and outputs if policy or managerial interventions were designed to increase instructional time for existing schools. Such interventions may be institutionally harder, though they would be cheaper in government outlays. Policy dialog is needed to help countries address their sources of "leakage" at the school level, teacher level, and classroom level and plan actions toward eliminating them. Earlier U.S. research showed that teachers use time better after they receive feedback, which supervisors can provide if they are attentive to this concept (Stallings, Needles, and Stayrook 1979). The important ingredient is large-scale "buy-in," particularly among busy policymakers who may consider this issue trivial.

The future of the Education for All initiative may depend on how seriously governments and donors take instructional time wastage. The international organizations financing education must ensure that the time governments buy for their students is actually spent in obtaining learning outcomes.

\section{Funding}

This research was financed by a grant from the Bank-Netherlands Partnership Program (no. TF052584). 


\section{Notes}

Helen Abadzi Senior Evaluation Officer, World Bank, Washington, DC 20433, USA (habadzi@worldbank.org). This article represents the author's opinions and should not be construed as representing the views of the World Bank or the Independent Evaluation Group.

\section{References}

Abadzi, H. 2006. Efficient Learning for the Poor: Insights from the Frontier of Cognitive Neuroscience. World Bank, Washington, DC.

2007. Absenteeism and Beyond: Loss and Costs of Instructional Time in Schools. Policy Research Working Paper Series. World Bank, Washington, DC.

Akhmadi, S.U., and Daniel Suryadarma. 2004. When Teachers Are Absent: Where Do They Go and What Is the Impact on Students? Jakarta: SMERU Research Institute.

Ali, M., and T. Reed. 1994. A School and Parental Survey of Book Provision Issues in NWFP. London: International Book Development, Ltd. Anderson.

Amadio, M. 1997. "Primary Education: Length of Studies and Instructional Time." Educational Innovation and Information 92:2-7.

1998. "Instructional Time and Teaching Subjects during the First Four Years of Primary Education." In Educational Innovation and Information 96. Geneva: UNESCO Bureau of International Education.

Anderson, L.W. 1976. "An Empirical Investigation of Individual Differences in Time to Learn." Journal of Educational Psychology 68(2):226-33.

Anderson, L.W., D.W Ryan, and B.J. Shapiro, eds. 1989. The IEA Classroom Environment Study. Oxford: Pergamon Press.

Atkinson, R.C. 1972. "Ingredients for a Theory of Instruction." American Psychologist 27:921-31.

Attar, M. 2001. "Ghana Country Report." In S. Pillai, ed., Strategies for Introducing New Curricula in West Africa. Geneva: IBE-UNESCO.

Barrier, Émilie, Sekou Fernández, Jeannot Saa Tinguiano, and Gononan Traore. 1998. "Évaluation du système éducatif guinéen." Centre international d'études pédagogiques, Sèvre et Cellule nationale de coordination de l'évaluation du système éducatif, Conakry.

Ben Jaafar, S. 2006. "An Alternative Approach to Measuring Opportunity-to-Learn in High School Classes." Alberta Journal of Educational Research 52(1):107-126.

Bloom, B. 1971. Handbook on Formative and Summative Evaluation of Student Learning. New York: McGraw Hill.

Bray, M. 2000. Double-Shift Schooling: Design and Operation for Cost-Effectiveness, 2nd edn. London: The Commonwealth Secretariat and IIEP-UNESCO.

2006. "Private Supplementary Tutoring: Comparative Perspectives on Patterns and Implications." Compare 36(4):515-30.

Carnoy, M., A. Gove, and J. Marshall. 2004. "Why Do Students Achieve More in Some Countries than in Others? A Comparative Study of Brazil, Chile, and Cuba." Paper presented in October at the World Congress of Comparative Education in Havana, Cuba.

Carroll, J. 1963. “A Model of School Learning.” Teachers College Record 64:723-33. 
Cerdan-Infantes, Pedro, and Christeel Vermeersch. 2007. "More Time is Better: An Evaluation of the Full-time School Program in Uruguay." Policy Research Working Paper 4167. World Bank, Washington, DC.

Chaudhury, N., J. Hammer, M. Kremer, K. Mularidharan, and H. Rogers. 2004a. Roll Call: Teacher Absence in Bangladesh. Development Economics Department World Bank, Washington, DC.

Chaudhury, N., J. Hammer, M. Kremer, K. Mularidharan, and H Rogers. 2004b. Teacher Absence in India. Development Economics Department World Bank, Washington, DC.

2004c. Missing in Action: Teacher and Health Care Provider Absence: A Multi-Country Study. Development Economics Department World Bank, Washington, DC.

Coleman, J.S., E.Q. Campbell, C.J. Hobson, J. McPartland, A. Mood, F. Weinfeld, and R.L. York. 1966. Equality of Educational Opportunity. Washington, DC: Office of Education, National Center for Education Statistics, U.S. Government Printing Office.

Das, J., S. Dercon, J. Habyarimana, and P. Krishnan. 2005. “Teacher Shocks and Student Learning: Evidence from Zambia." World Bank Policy Research Working Paper 3065, Washington, DC.

De, Anuradha, and Jean Dreze. 1999. "Public Report on Basic Education in India (PROBE)." New Delhi: Oxford University Press.

Dia, E.C. 2003. "Instructional Time in Primary School: The Cases of Burkina Faso and the Gambia." Paper prepared for HDNED. World Bank, Washington, DC.

Diouf, Adama. 2005. "Temps scolaire et qualité des apprentissages dans les collèges et lycées." Unpublished MS, Diourbel, Senegal.

Duflo, E., and R. Hanna. 2005. "Monitoring Works: Getting Teachers to Come to School.” Mimeo, MIT.

EARC (Educational Assessment and Research Center). 2003. "Teacher Time on Task." United States Agency for International Development, unpublished report. Educational Assessment and Research Center, Ghana.

EDUCA. 2005. "Uso del Tiempo en la Escuela Dominicana." Encuesta EDUCA-GALLUP, Santo Domingo, Dominican Republic.

Fisher, C.W., and D.C. Berliner, eds. 1985. Perspectives on Instructional Time. New York: Longman.

Fisher, C.W., N.N. Filby, R.S. Marliave, L.W. Cahen, M.M. Dishaw, J.E. Moore, and D.C. Berliner. 1978. “Teaching Behaviors. Academic Learning Time and Student Achievement." Technical Report V-1, Final Report of Phase III-B, Beginning Teacher Evaluation Study. San Francisco: Far West Laboratory for Educational Research and Development.

Fredrick, W., and H. Walberg. 1980. "Learning as a Function of Time." Journal of Educational Research 73(4):183-94.

Fuller, B. 1987. "What School Factors Raise Achievement in the Third World?" Review of Educational Research 57:255-92.

Fuller, B., and P. Clarke. 1994. "Raising School Effects While Ignoring Culture? Local Conditions and the Influence of Classroom Tools, Rules and Pedagogy." Review of Educational Research 64: $119-57$.

Gettinger, M. 1984. "Individual Differences in Time Needed for Learning: A Review of the Literature." Educational Psychologist 19:15-29.

. 1989. Effects of maximizing time spent and minimizing time needed for learning on pupil achievement. American Educational Research Journal 26:73-91.

Glewwe, P., M. Kremer, and S. Moulin. 1999. Textbooks and Test Scores: Evidence from a Prospective Evaluation in Kenya. World Bank Draft, World Bank, Washington, DC. 
Greenwood, C. 1991. "Longitudinal Analysis of Time, Engagement and Achievement in At-Risk Versus Non-Risk Students." Exceptional Children 57(6):521-35.

Heyneman, S., and W. Loxley. 1983. "The Effect of Primary School Quality on Academic Achievement across Twenty-Nine High and Low Income Countries." American Journal of Sociology 88(6):1162-94.

Huyvaert, S.H. 1998. Time is of the Essence: Learning in Schools. Needham Heights, MA: Allyn \& Bacon.

IEG (Independent Evaluation Group). 2008. "Mozambique: Education and Manpower Development Project (Credit 1907); Second Education Project (Credit 2200); Capacity Building Human Resources Development Project (Credit 2436); Education Sector Strategic Program Project (Credit 3172)." Project Performance Assessment Report. World Bank, Washington, DC.

Jencks, C. 1972. Inequality: A Reassessment of the Effects of Family and Schooling in America. New York: Basic Books.

Karweit, N. 1976. "A Reanalysis of the Effect of Quantity of Schooling on Achievement." Sociology of Education 49:236-46.

1983. Time on Task: A Research Review. Baltimore, MD: The John Hopkins University, Center for Social Organization of Schools.

Kim, Kyeh. 1999. "Comparative Study of Instructional Hours in West Africa." Informal Report, AFTHR. World Bank, Washington, DC.

King, E.M., P.F. Orazem, and E.M. Paterno. 1999. Promotion With and Without Learning: Effects on Student Dropout. World Bank, Washington, DC.

Knight, Stephanie L. 2006. "History and Use of the Stallings Observation System in the World Bank International Time on Task Project." Paper presented at the American Educational Research Association Conference, San Francisco, April.

Kremer, M., K. Muralidharan, N. Chaudhury, J. Hammer, and H. Rogers. 2005. "Teacher Absence in India." Journal of the European Economic Association 3(2-3):658-67.

Lavy, Victor. 2001. "Estimating the Effect of School Time of Instruction on Student Achievements." Hebrew University Economics Working Paper 01-4. Social Science Research Network Electronic Library, Washington, DC.

Lewis, M., and M. Lockheed. 2006. Inexcusable Absence: Why 60 Million Girls Still Aren't in School and What to Do About it. Washington, DC: Center for Global Development.

Linden, T. 2001. Double-Shifts Secondary School: Possibilities and Issues. World Bank, Washington, DC.

Lockheed, M., and A. Harris. 2005. "Beneath Education Production Functions: The Case of Primary Education in Jamaica." Peabody Journal of Education 80(1):6-28.

Lockheed, M., and A.M. Verspoor. 1992. Improving Primary Education in Developing Countries. New York: Oxford University Press.

Lloyd, C.B., S. El Tawila, W. Clark, and B. Mensch. 2003. "The Impact of Educational Quality on School Exit in Egypt." Comparative Education Review 47(4):444-67.

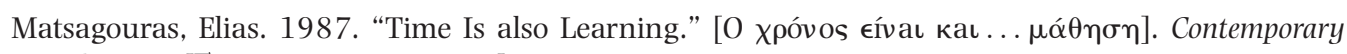

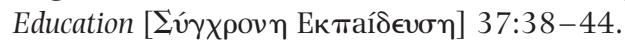

Millot, B., and J. Lane. 2002. "The Efficient Use of Time in Education." Education Economics 10: 209-28.

Njie, F. 2001. “Gambia Country Report.” In S. Pillai, ed., Strategies for Introducing New Curricula in West Africa. Geneva: IBE-UNESCO.

OED (Operations Evaluation Department). 2002. "Brazil. Innovations in Basic Education Project (Loan 3375-BR); Second Northeast Basic Education Project (Loan 3604-BR); Third Northeast 
Basic Education Project (Loan 3663-BR); School Improvement Project-FUNDESCOLA I (Loan 4311-BR).” Project Performance Assessment Report. World Bank, Washington, DC.

2004. Books, Buildings, and Learning Outcomes: An Impact Evaluation of World Bank Support to Basic Education in Ghana. World Bank, Washington, DC.

2005. "Niger: First Education Project (Credit 1151-NIR); Primary Education Development Project (Credit 1740-NIR); Basic Education Sector Project (hybrid)—(credit 2618-NIR).” Project Performance Assessment Report. World Bank, Washington, DC.

Patrinos, H.A., and R. Kagia. 2007. "Maximizing the Performance of Educational Systems: The Case of Teacher Absenteeism." In J. Edgardo Campos, and Sanjay Pradhan, eds., The Many Faces of Corruption: Tracking Vulnerabilities at the Sector Level. World Bank, Washington, DC: 63-84.

Quartarola, B. 1984. "A Research Paper on Time on Task and the Extended School Day/Year and their Relationship to Improving Student Achievement." Sacramento, CA: Research, Evaluation, and Accreditation Committee, Association of California Administrators.

Rabenstein, R.L., N.A. Addy, B.J. Caldarone, Y. Asaka, L.M. Gruenbaum, L.L. Peters, D.M. Gilligan, R.M. Fitzsimonds, and M.R. Picciotto. 2005. "Impaired Synaptic Plasticity and Learning in Mice Lacking Adducing, an Acting-Regulating Protein." The Journal of Neuroscience 25:2138-45.

Reimers, F. 1993. "Time and opportunity to Learn in Pakistan's Schools: Some Lessons on the Links between Research and Policy." Comparative Education 29(2):201-12.

Rogers, H.F, J. Lopez-Calix, N. Chaudhury, J. Hammer, N. Cordoba, M. Kremer, and K. Muralidharan. 2004. Teacher Absence and Incentives in Primary Education: Results from a National Teacher Tracking Survey in Ecuador. Development Economics Department World Bank, Washington, DC.

Rosenshine, B.V. 1979. "Content, Time and Direct Instruction.” In P.L. Peterson, and H. Walberg, eds., Research on Teaching: Concepts, Findings and Implications. Berkeley, CA: McCutchean: 28-56.

Sathar, Z.A., C.B. Lloyd, M. ul Haque, M.J. Grant, and M. Khan. 2005. Fewer and Better Children: Expanding Choices and School Fertility in Rural Pakistan. New York: Population Council, Policy Research Division.

Sen, A. 2002. "An introduction". In Pratichi Trust, ed., Pratichi Education Report: A Study in West Bengal. New Delhi: TLM Books.

Smith, B. 2000. "Quantity Matters: Annual Instructional Time in an Urban School System." Educational Administration Quarterly 36(5):652-82.

Smyth, J. 1985. "A Context for the Study of Time and Instruction." In C.W. Fisher, and D.C. Berliner, eds., Perspectives on Instructional Time. New York: Longman: 3-27.

Stallings, J. 1975. "Implementation and Child Effects of Teaching Practices in Follow through Classrooms." Monograph of the Society for Research in Child Development 40(163).

1980. "Allocated Academic Learning Time Revisited, or Beyond Time on Task." Educational Researcher 9(11):11-16. [Summarized in Effective Schools Research Abstracts 1(6)].

1985a. "Instructional Time and Staff Development." In C.W. Fisher, and D.C. Berliner, eds., Perspectives on Instructional Time. New York and London: Longman: 283-98.

1985b. "Implications from the Research on Teaching for Teacher Preparation." In I.E. Housego, and P.P. Grinunett, eds., Teaching and Teacher Education: Generating and Utilizing Valid Knowledge for Professional Socialization. Vancouver: The University of British Columbia, Centre for the Study of Teacher Education, Faculty of Education: 161-79.

2006. "Results of Classroom Observations in Tunisia, Morocco, Ghana, and Brazil." Paper Presented at the Annual Meeting of the American Educational Research Association, San Francisco, California. 
Stallings, J., and D. Kaskowitz. 1974. Follow through Classroom Observation Evaluation, 1972-1973. Menlo Park, CA: Stanford Research Institute.

Stallings, J., M. Needles, and N. Stayrook. 1979. How to Change the Process of Teaching Basic Reading Skills, in Secondary Schools. Menlo Park, CA: SRI International.

Stevens, FE. 1993. "Applying an Opportunity-to-Learn Conceptual Framework to the Investigation of the Effects of Teaching Practices via Secondary Analyses of Multiple-Case-Study Summary Data." The Journal of Negro Education 62(3):232-48.

Sultana, Ronald. 2006. Facing the Hidden Dropout Challenge in Albania. Tirana: UNICEE.

Suryadarma, D., A. Suryahadi, S. Sumarto, and H. Rogers. 2004. The Determinants of Student Performance in Indonesian Public Primary Schools: The Role of Teachers and Schools. World Bank and SMERU, Washington, DC and Jakarta, Indonesia.

Tietjen, K., A. Rahman, and S. Spaulding. 2004. Time to Learn: Teachers' and Students' Use of Time in Government Primary Schools in Bangladesh. Basic Education and Policy Support (BEPS) Activity Creative Associates International (USAID).

Vermeersch, C., and M. Kremer. 2004. "School Meals, Educational Achievement and School Competition: Evidence from a Randomized Evaluation." Policy Research Working Paper 3523. World Bank, Washington, DC.

Walberg, H.J. 1988. "Synthesis of Research on Time and Learning." Educational Leadership 45(6): $76-85$.

Walberg, H.J., and W.C. Fredrick. 1991. Extending Learning Time. Washington, DC: U.S. Department of Education.

Wang, J. 1998. "Opportunity to Learn: The Impacts and Policy Implications." Educational Evaluation and Policy Analysis 20(3):137-56.

Watkins, Kevin. 2000. The Oxfam Education Report. Bath, UK: Redwood Books.

Wiley, D.E., and A. Harnischfeger. 1974. "Explosion of a Myth: Quantity of Schooling and Exposure to Instruction: Major Education Vehicles." Educational Researcher 3:7-11.

World Bank. 1997. Primary Education in India. World Bank, Washington, DC.

2008. "Implementation Completion and Results Report (Ida-34970 Ida-3497a Jpn-53767) on a Credit in the Amount of Sdr32.3 Million (US\$ 41.5 Million Equivalent) to the Republic of Honduras for a Community-Based Education Project." Latin America and the Caribbean Region, Report Icr0000714. Washington, DC.

World Bank and IADB (Inter-American Development Bank). 2000. Brazil Secondary Education in Brazil: Time to Move Forward. World Bank, Washington, DC.

Yair, G. 2000. "Not just about Time: Instructional Practices and Productive Time in School." Educational Administration Quarterly 36(4):485-512. 